\title{
Open Secrets and Knowing Smiles
}

\begin{abstract}
Given the importance of informal ways of getting things done in postsocialist societies, research into the field of unwritten rules and informal practices has been slow to develop. In studying such rules and practices, the researcher often encounters skepticism or hostility stemming from the ways in which people relate to tacit agreements. Or else, she is greeted by an ambivalent smile of complicity-a knowing smile. In this article I draw a connection between knowing smiles and open secrets and argue that these notions illuminate a great deal about how the 'grey areas' of social life function. I suggest that such seemingly trivial aspects of day-to-day life can reveal profound features of social institutions and point in the direction of innovative research.
\end{abstract}

This paper is the outcome of years of exposure to people's reactions to my research in Russia. When I did my fieldwork there in the 1990s and asked people to talk to me about blat - the use of personal networks for obtaining goods and services in short supply and for circumventing formal procedures - they smiled knowingly but then almost universally responded "Why ask me?" Reassured that I only want to know "what everybody knows," most of my respondents were happy to discuss blat matters frankly, talking about others, 
in generic terms, or about the past, but also coming up with personal examples. ${ }^{1}$ There were stronger reactions - my Russian academic advisor almost threw me out of her home when I explained which $\mathrm{PhD}$ topic I was working on, dismissing it as trivial or 'westernized.' Fellow Russian academics sometimes refer to it in a disparaging way, people from Russian regions show disbelief that such a topic could constitute a subject matter of serious analysis and the witty come up with the pun "a PhD by blat, you mean?" Similar reactions followed my subsequent research into practices of black and grey piar (methods of political marketing and campaigning), related practices of kompromat (use of compromising materials), financial and barter scheming, telefonnoe pravo (oral commands and pressure on the judiciary) and other informal practices widespread in postSoviet Russia.

I refer to one country, my country of origin, but I believe that my findings might be relevant for comparative study. My question is: 'Why do people smile about commonplaces that are strictly speaking neither funny nor enjoyable in any obvious way?' I split this question into three components: what is smiled at, how it is smiled at and what these smiles do. First, I argue that knowing smiles are indicative of open secrets, elusive in nature and intentionally ambiguous. Secondly, I analyze ambiguities of open secrets that knowing smiles disclose. Thirdly, I offer an interpretation of the subtlety and depth of seemingly superficial interactions exchanged in passing. I rely on the secondary analysis of materials used in my books and some new interviews but from an angle entirely left out of my previous research.

When writing about theoretical commonplaces, Svetlana Boym recalls a peculiar form of "understanding with half-words" among Soviet intelligentsia as a mark of 
belonging to an imagined community that exists on the margin of the official public sphere. "Communication with half-words secures the unspoken realm of cultural myths and protects the imagined community from outsiders and, in a way, from its own members," she writes. I argue that knowing smiles are a visible sign of sharing and belonging, but are at the same time an expression of ambivalence. They are the signals of competence similar to a reaction of laughing at a joke but expressed in a non-humorous context, thus being robbed of the nature of the smile and loaded with the pressure of knowledge. 'Knowledge of what?' is our first stop.

\section{Unwritten rules}

Consider Russia's popular wisdom: 'Russia is a country of unread laws and unwritten rules'. Or, as they say, 'the imperfection of our laws is compensated for by their nonobservance' (nesovershenstvo nashikh zakonov kompensiruetsya ikh nevypolneniem). This is a hint that would cause a flicker of a knowing smile or a chuckle. It is not that the requisite components of the rule of law are absent in Russia; rather, the ability of the rule of law to function coherently has been diverted by a powerful set of practices that has evolved organically in the post-Soviet milieu. An immediate grasp of the gap between the way things are claimed to be and the ways things are in practice constitutes an advantage enjoyed by an insider over outsiders, much more reliant on written sources of competence. The unwritten rules are non-verbal yet essential in understanding the order of things, whether in politics, economy or society. ${ }^{2}$

Unwritten rules are not about knowing the rules, they are about shared rulefollowing. Knowing a rule does not imply an ability to follow it, or mastery of it, just as 
knowing a recipe does not assure practical skill in its implementation or knowing the literal meaning of a word does not automatically mean that one will use it correctly in context. In Wittgenstein's terminology there are practices of 'rule-following' (i.e. being able to continue the sequence of numbers $2,4,6,8, \ldots)$ that are distinct from rules interpreted, explicated and understood (i.e. an ability to figure out the formulae of this sequence). In a classic example of chess playing, Wittgenstein shows that certain mastery and expertise can only be achieved by dealing with constraints in practice.

A distinction between a rule and mastery of the rule can be illustrated by the metaphor of driving in Russia. To drive 'properly,' one has to mix both formal (traffic rules) and informal codes (conventions); to apply them as needed in appropriate contexts and to switch fluidly between them; and crucially, to negotiate oneself out of trouble if caught. This is apart from struggling to avoid potholes or traffic jams on the road by radical maneuvers and preserving an informal hierarchy of vehicles doing the same. In other words, unwritten rules are not only about how to follow the rules of the game but also about how to break them.

Unwritten rules are the know-how needed to 'navigate' between formal and informal sets of constraints. Without being articulated, they 'prescribe' which rules to follow in which context and 'set' the best approach for getting things done. Applying one formal rule rather than another, using restrictions (quotas, filters etc.) and small print, enforcing some decisions but not the others are examples of how constraints can be mediated. The focus of unwritten rules is not on constraints per se, as in the case of formal and informal codes, but on the enabling aspects of those constraints. To put it more bluntly, unwritten rules define the ways of circumventing constraints, both formal 
and informal, of manipulating their enforcement to one's own advantage and of avoiding penalties by combining the three elements of the rules of the game creatively. ${ }^{3}$

Unwritten rules exist in all societies, but predominate (and even become indispensable) in conditions of over-regulation and under-enforcement of formal rules; and especially where formal rules and informal codes do not constitute coherent rules of the game. North shows that when people perceive the structure of the rules of the system to be fair and just, transaction costs are low and enforcement costs are negligible, which helps the efficiency of the economy. ${ }^{4}$ When people perceive the system to be unjust, the costs of transactions go up. In other words, if one cannot follow both formal and informal sets of constraints coherently, this will be reflected in their merger and certain patterns of rule-following or unwritten rules. It might be tempting to think that unwritten rules are generally disadvantageous for the system. This is only true, however, if the rules of the game - formal and informal constraints and their enforcement - were tied to the public interest and were beneficial to economic performance. As this has not always been the case in Russia, the impact of unwritten rules is rather ambivalent.

Cultural traditions in Russia separate the concept of justice from that of formal law, which is grasped in a discrepancy in connotations between the terms spravedlivost' (justice) and zakonnost' (lawfulness). In his study of Muscovite Political Folkways, ${ }^{5}$ Edward Keenan explains such a gap between the informal and the formal in terms of political culture and distinguishes its enduring elements:

- the operational basis of each setting is informal and traditional (lacking a necessary connection between real power and formal status);

- decision-making is corporate and conspiratorial; 
- stability and risk-avoidance are favoured over innovation and progress; and

- there is a reluctance to promulgate systematic codified law (those who need to know the rules know them).

Keenan's conclusions about the nature of the Soviet system (his analysis predated the end of the USSR) have relevance for the examination of the post-Soviet era as well. These attributes of the system have not changed much during Russia's transition to a market economy. In the same way that the planned economy was not really a planned economy and was actually run with help of tolkachi ('pushers' for the plan completion in industry), blat (use of personal networks for getting things done), pripiski (false reporting) and other informal practices, the market economy today is not really a market economy. This is due primarily to the key role that unwritten rules still play in the system. ${ }^{6}$ The state is partly responsible.

Over the course of the 1990s, the public felt betrayed by the outcomes of privatization and placed all the blame on state institutions and bureaucrats who found ways to prosper, while abandoning the general population to its own devices-which facilitated petty corruption. At the level of 'state capture' and political corruption, the role of the state as a major shareholder in many large corporations is noteworthy. Insider deals have prevailed (particularly since 1995) as a method of state assets disposal, and other opaque corporate governance arrangements have proliferated. ${ }^{7}$ Since the 2000s, similar methods have been used for the state to reassert its control over the strategic sectors and key industries. These deals are impossible to decode without understanding the gap between formal institutions and informal ways of operating them, as well as it is impossible to fully decipher the 'information wars' and 'kompromat (compromising 
material) wars' omnipresent in Russia of the 1990s. ${ }^{8}$ Unwritten rules also have played part in regulating non-monetary exchanges. Barter chains redistributing income among the 'inner circle,' as well as among firms and their multiple subsidiaries, have revolutionized practices of 'give-and-take' and have provided them with a legally amenable form. ${ }^{9}$

All of these phenomena of the new Russian economy share an important featureagents at all levels employ practices that have come to be known as extralegal or informal - that is widely recognized. Yet the competence in agents' mastery of unwritten rules is highly stratified. We might all smile in recognition of the gap between formal pronouncements and realities of the post-Soviet period but these general 'open secrets' about Russian privatization will remain 'secrets' for the majority of the public when it comes to detail. The stratified nature of open secrets (in particular professions, institutions, industries, enterprises, and even collectives and networks) is of direct relevance to our analysis of 'knowing smiles' and is to be considered next. ${ }^{10}$

'Common knowledge' about the gap between the official discourse (whether on planned economy or market democracy) and the ways in which things are done in practice (like tolkachi and blat or financial scheming and managed democracy) constitutes an open secret. Exploring that gap and the ways in which it is bridged in a particular domain, identifying 'grey areas' and distinguishing 'shades of grey' are challenges for both researchers and policymakers. Commonplaces and other trivial aspects of day-to-day life can sometimes reveal profound features of societies that are hidden when tackling them directly. My methods here can be illustrated by Freud's celebrated example of art forgery. To discover whether a painting is a forgery or not, the most effective way is to focus on 
minor details, such as how the painter depicts fingernails or the slope of a thumb. Most forgers can fake the major aspects of what is portrayed - it is the tiny details that give them away. Freud argued the same is true of 'trivial' aspects of day-to-day life, like slips of the tongue. The apparently trivial elements are the key to understanding core dispositions of the personality and equally I am making the same argument about the 'disclosure' of open secrets that the knowing smile represents. In developing this point I draw upon a variety of sources-Freud, Goffman, Simmel and Bourdieu-and seek to bring their insights together. I have had to be inventive. So far as I can trace, neither knowing smiles nor open secrets have been analyzed in the social sciences, let alone the relationship between them.

\section{Open Secrets}

As a concept, an "open secret" has some resemblance to Torstein Veblen's paradoxical concepts of "trained incapacity," "conspicuous consumption," "trained incapacity," or to Peter Sloterdijk's model of “enlightened false consciousness," which clash their mutually exclusive parts in order to create a new meaning. People's reactions to the paradox of 'unread laws and unwritten rules' - the knowing smiles - are the acknowledgement of understanding of such meaning, the meaning of the failed purpose. For example, in the famous folklore definition of the six paradoxes of late socialism every paradox pointed to an open secret - an informal practice, widespread but hidden from outsiders: absenteeism in 'no unemployment but nobody works'; false reporting in 'nobody works but productivity increases'; shortages in 'productivity increases but shops are empty'; blat in 'shops are empty but fridges are full'; unfair privileges in 'fridges are full but nobody is 
satisfied'; cynicism in 'nobody is satisfied but all vote unanimously.' These practices were not really unknown but 'shameful' for socialism and therefore hidden from the official discourse - thus making them its open secrets of socialism. Practical, or tacit, knowledge of the tensions expressed in paradoxes make smiles even more knowing. ${ }^{11}$ For insiders, it is not only about knowing an unwritten rule or an open secret in question, but also about social competence of handling them with an appropriate knowing smile in an appropriate context. Belonging and complicity expressed in knowing smiles reflect the key paradox of the totalitarian power that generated a 'homo Sovieticus' who brought it to its end. So went the seventh, post-socialist paradox: 'all voted unanimously but the system collapsed anyway.'

One might think that an open secret is not a secret at all, since it concerns things that 'everyone knows', whether within a particular group or more widely in a society. This view would be a mistake, however, because open secrets are only partly open. Open secrets are secrets in the sense that they are excluded from formal or official discourse but they are open in the sense that they are familiar and referred to in idioms and language games, though these often require explanation for outsiders. The ambiguity involved is a real and significant one. There is a tacit acceptance that what is known should remain unarticulated. Open secrets occupy areas of tension, where a public affirmation of knowledge would threaten other values or goods that those involved want to protect. This point is noted in Georg Simmel's discussion of secrecy, which reveals its complexity and subtlety. Simmel defines secrecy as 'consciously willed concealment'—open secrets are clearly still secrets according to this definition. Simmel makes the point that secrecy is a relative phenomenon, at least as soon as it is shared: 'a secret that two know is never a 
secret. ${ }^{12}$ Goffman takes the idea further by opposing diplomatic, official and strategic secrets to secrets that presuppose everyday familiarity with one another's doings. ${ }^{13}$ The degree of openness is likely to correspond to the reaction when the secret is revealed or spoken about. ${ }^{14}$ However, he does not use the concept 'open secret' as such, nor does he pursue an argument as stated in this article. I define an open secret as unarticulated knowledge that everybody who is party of a transaction knows about but which no-one discusses in a direct way. There is considerable continuity in attitudes to open secrets between the later years of the Soviet Union and post-Soviet period, so we have to retrace briefly the evidence of open secrets that surface in the Soviet satire.

In late Soviet movies, such as Danelia's Afonia (1975), Mimino (1977), Osennii maraphon (Autumn Marathon, 1979), Riavanov's Ironiia sud'by (The Irony of Fate, 1975), Sluzhebnyi roman (An Office Romance, 1977), Garazh (The Garage, 1979) and Bortko's Blondonka za uglom (The Blond Around the Corner, Bortko, 1984), convey attitudes regarding informal practices that are light and playful, even if meant to be corrective. ${ }^{15}$ They are 'satiricized' rather than genuinely satirical and target particular groups that engage in these practices rather than the practices themselves. Similar to Krokodil images, satirical films sought to co-opt Soviet audiences into a stigmatizing laughter, but at the same time they introduced techniques of handling open secrets and defined the boundaries of what was considered possible.

Commonly recognized but rarely registered in written sources, apart from their "satirized" or "critical in a controlled way" images, inevitably linked with the defects of particular individuals rather than attributed with a systemic character, these practices testified to various ways in which socialism failed to satisfy individual needs. "Satirized" 
images of Krokodil were acceptable because they never targeted the intrinsic failures of the Soviet system. Just about every part of everyday life was satirized, if not in the controlled discourse of Krokodil, then in anekdot. The failures of the system were out in the open but not acknowledged as systemic. They didn't appear in the proceeding of the Central Committee. That's what censorship did - it did not allow the formal admission of a failure on the part of the system-while reading official sources one could never come to the conclusion that the system that had emerged in the Soviet Union intrinsically was doomed to failure. ${ }^{16}$ The system could not exist without people circumventing the declared principles and was in fact dependent on people to take care of the systemic defects and to lubricate the rigidities of its constraints. ${ }^{17}$ The failures of the Soviet system, which all the insiders were complicit in reproducing, were its main open secrets, satirized, smiled at but... kept! ${ }^{18}$

Thus, on the one hand, blat was commonplace and its instances could make the front page of Krokodil in 1980s (without using the word blat). On the other hand, the political system keeps its reliance on informal practices hidden and shifts the responsibility for engaging in informal practices to individuals. Krokodil helped to promote the narrative of the "grand misrecognition game": everybody does it (engages in informal practices, unofficial discourse, 'doublethink') but it has nothing to do with socialism. Although designed to create humor, Krokodil could not help being part of the political repressive machinery designed to introduce and reinforce moral/political standards. Uncovering a form of politics that pretends to be humor reveals a dimension of power that Bourdieu referred to as symbolic violence. 
As a form of controlled critique, Krokodil exercised the power of tension management in a number of ways. Being the main official publication that referred to informal practices, Krokodil—itself perhaps being a form of false reporting—declared to perform the functions of producing Soviet satire, of eradicating social ills, and of giving a platform for revealing critique and self-critique (samokritika) for the system but could not deliver. Officially published and therefore working within the boundaries established by the ideological constraints, Krokodil was only partially about the satire- but partially it was about adequate "framing" of social ills and their "satirization." By introducing themes and boundaries - what to smile at, how and where-Krokodil socialized and educated the Soviet public on the matters of everyday life. ${ }^{19}$ On its pages one can see some depictions of the 1930s, 1950s, 1980s but not others and therefore conclude what can be discussed, criticized and satirized and what cannot (this function of Krokodil would be similar to satirical publications in other societies). While claiming the task of eradication of social ills, Krokodil also was engaged in educating the public on how to react to certain themes and concerns. It was a pedagogical device, like most Soviet mass culture, assisting the "misrecognition game" of every historical period. ${ }^{20}$ The ways of revealing social ills to the public were also the ways of concealment. Most importantly, Krokodil inverted the role that satire has in other societies - to criticize - into the one that it does not have in other societies- to de-moralize people and to make them complicit in the failures of the regime. It wasn't just about force, oppression, rewards for co-optation or inclusion that brought people into that system-it was through the smile and shared mastery of the system. 
By the 1980s, understanding of the formal (and enabling) nature of constraints and acknowledgement of the possibility of circumventing them became almost universal—a variety of know-how was shared by insiders of a circle, a group or society as a whole. Depending on the reference group, open secrets varied in degree of openness. Blat is an example of a widely acknowledged open secret—even twenty years since the collapse of the Soviet Union, only $7 \%$ of an all-Russia national survey found it difficult to define blat, in contrast to $30 \%$ having difficulty in defining another late Soviet practice of telefonnoe pravo (telephone justice), standing for oral commands to the judiciary. ${ }^{21}$

\section{Knowing Smiles}

In a way, the very question 'Why do people smile about open secrets that are neither funny nor enjoyable in any obvious way?' may already suggest an answer. A knowing smile is not a smile of joy or laughter. Even if reminiscent of the Russian literary tradition of 'laughter through tears, ${ }^{, 2}$ the knowing smile is relieved of intense emotions because of the mundane nature of open secrets - the familiarity that brings contempt rather than laughter or tears.

I identify a knowing smile as a routine signal of acknowledgement and competent mastery of open secrets, where the emotional content is minimal. Conceptually, the knowing smile is not about facial expressions of emotions. Ekman describes many kinds of smiles, from the 'felt' smile to the fear smile, the contempt smile, the dampened smile, the miserable smile, and a number of others but warns against a non-specialist deciphering the person's less routine signals. ${ }^{23}$ He points out that until very recently, both scientists and laymen knew very little about emotion, despite its importance in human 
lives and there are reasons for it: "it is in the nature of emotion itself that we would not fully know how emotions influence us and how we recognize their signs in ourselves and others." ${ }^{24}$ Ekman argues that emotions can begin and change so quickly that our conscious self does not participate in or even witness what in our mind triggers an emotion at any particular moment.

I therefore do not seek to identify or interpret emotions behind the knowing smiles that I tend to come across in the field. In tune with analytical bias of social sciences, I am more interested in knowing smiles as pointers to the open secrets and the non-articulated knowledge that people prefer to leave ambiguous. Using material from my previous and current research, I construe ideal types of knowing smiles that reflect possible patterns of mastery of blat, as a proxy of an open secret, based on emotions displayed, identified or used for rationalization by my respondents. Knowing smiles about blat can be associated with three basic attitudes to open secrets—'positive,' 'neutral' and 'negative'—perhaps concealing a varying degree of personal involvement and illustrating forms of dealing with ambivalence.

At a very basic level, chats about blat produce a smile of linguistic recognition. As was expressed best by Zhvanetskii: 'only those who belong would understand...' (tol'ko svoi ponimaet kak prinosit' pol'zu obschestvu vopreki ego zhe zakonam). The pleasure of sharing untranslatable 'games of words,' behind which, in Zhvanetskii's satirical piece, hide the untranslatable "games of deeds" - what I call informal practices— provides a sense of belonging to a circle of people who "know how." 25 Just as it is a pleasure to recognize a foreign idiom or understand a joke, it is enjoyable to recognize a native 'language game' that points to an open secret that might be tricky for a foreigner to 
understand. A knowing smile of belonging ("we are all complicit in our own oppression and in our own corruption") is most common but it also has an implication of dividing us and them, "subconsciously indicating secret pleasure from co-operation" between us against them. "Us" implies complicity of people of the circle who care about each other. "Them" refers to the state, strangers, or outsiders, who take care of themselves. Such division is representative of what Gudkov has referred to as 'negative identity. ${ }^{26}$

Other knowing smiles associated with guilty pleasures include the one of the "pleasure of doing something wrong," the "pleasure of perversion;" the "pleasure of crossing boundaries in the society which is overregulated;" or, in Sloterdijk's phrase, "the crooked smile of open immortality." Empowering an individual through crossing some boundaries, conscious or unconscious, feeds into one of the central themes in my study of informal practices - the enabling power of constraints. Knowing smiles (audacious, mischievous or naughty) can imply active use of constraints; "positive opportunism," experience of turning the weaknesses of the system (prokoly sistemy) to one's advantage, known as "cheating the state" or "beating the system," all pointing to the satisfaction from covert systems of rewards and abuse of state institutions in totalitarian regimes.

Reactions associated with indifference and a weak emotional charge-the knowing smiles associated with ignorance, apathy or acceptance-are no less important. Dismissive smiles "undermine the significance of the issue or indicate lack of interest or concern" while accepting smiles can display anything from admission of the necessity of blat involved, directly or indirectly"), the individual helplessness vis-à-vis the regime, as well as the overall acceptance of the ways things are, failure or not. Often, the knowing smile is a way of disguising ignorance and erroneous associations. ${ }^{27}$ In such cases, the 
knowing smile is a cover for not understanding the processes at work- "of course I understand what's going on"-when in fact, it is a form of laziness. Neutral smiles not only emphasize the openness of open secrets and the widespread scale of blat practices, but also provide an escape route from taking them seriously by turning them into a smiling matter. They tackle uncertainty and display a passive habit of acceptance, the habitus $^{28}$ of Homo Sovieticus that ensures that one does not articulate or even question what the open secret really is about while smiling knowingly. Neutral knowing smiles are similar to what Goffman identifies as 'civil inattention,' and are thus most functional in signaling and testifying normality ("the unserious nature of practices as opposed to the big corruption scandals") and enabling people to 'go on. ${ }^{29}$

More negative knowing smiles can be associated with containment of embarrassment, shame or guilt. These smiles (shifty, awkward, uncomfortable, nervous smiles) present a way of "easing out of the situation" or a defense reaction. Following Bourdieu, I describe a number of strategies by which one can be involved in blat transactions while also misrecognising doing so - misrecognition as a system of denial, as a system of ambivalence, and as a system of power. ${ }^{30}$ The intermediation of blat transactions is essential to protect one's positive and altruistic self-image and to misrecognise one's own experiences: one helps a friend, not oneself, and that friend returns a favor eventually. Both parties maintain a 'good friend' self-image while using public resources for 'non-selfish' purposes. When the moral norms prescribe that one must help a friend but also that blat is immoral and unethical, the 'misrecognition game' is the way out. This is the key function of the 'misrecognition game'- to serve the situations of moral or logical squeeze, to deal with the paradoxes of the system, and in 
this particular case to allow personal engagement in blat practices while blaming it as a generic practice. "Blat is everywhere but what I do is not blat" is the key defensive narrative of respondents. ${ }^{31}$

The subtlety of the misrecognition game has informed my methodology of research on informal practices: speak about generic practice, not personal experience; let the experience trickle down through narrative; speak about others (neighbors, other firms, friends); speak about the past if the research is about know-how that is no longer in use. That is to say, one cannot study open secrets by speaking about them directly - they have to be taken into a comfort zone. In a way, studying paradoxes requires a correspondingly paradoxical methodology: the most direct way of studying an open secret is to study it indirectly; to find it one should not look for it; to develop marginality to see what's on the inside; to go away to see the bigger picture; to use the "rear mirror" methodology etc. In the context of studying open secrets, knowing smiles are essential, following Goffman, to assess the most profound features of societies through seemingly trivial aspects of everyday behavior. Sensitivities displayed in people's accounts and explanations of knowing smiles provide insights on their own relationship with the open secrets, as well as on relationships within their networks and possibly also their projection of the interviewer. ${ }^{32}$ An additional challenge for a researcher of sensitive practices is to historicize their elusive meaning defined by period, place and context (including all varieties of collective identities - - a challenge taken up by the growing field of the history of emotions. ${ }^{33}$ In the beginning of the 1990s, it became possible to ask people to articulate their views on Soviet informal practices without constraint, just as in the 1950s, those who left the Soviet Union were able to describe their blat experience in the Harvard 
Interviewing Project, ${ }^{34}$ the collapse of the Soviet Union have made blat a matter of the past and thus enabled people to articulate it.

\section{What do knowing smiles do?}

When reciprocated, the knowing smile is a sign of sharing awareness and ability "to read between the lines," "to see behind the façade," with some complicity in "beating the system" but without shouting out the "emperor has no clothes" secret. To put it in Simmel's terms, "although at first sight an empty form, [a knowing smile-AL] is an excellent symbol of that reciprocal apprehension, which is the presumption of every social relationship." ${ }^{35}$ The 'emptiness' of the knowing smile may signify the inability to articulate tacit knowledge (the actual workings of paradoxes are complicated) ${ }^{36}$ but it enables the reproduction of daily interactions without pressure of recognition of one's own compromised behavior or the failures of the system. It allows people to go on with their everyday lives and helps the system to reproduce itself. The 'emptiness' of the knowing smile is also relevant in the sense that knowing smiles in the stagnation period would not be the same as the knowing smile under Stalinism-its content is contextual and defined by whatever social competence may involve in a particular period.

All types of knowing smiles have a common denominator-the social competence of handling open secrets and dealing with situations of moral ambiguity or ethical squeeze, regardless of expressed attitude or emotional load. Social competence embraces tacit knowledge about what's normal, the ability 'to go on,' a skill to turn formal constraints to one's advantage and a capacity to play the 'doublethink' game in selfdefense and in the defense of the system people lived under. It implies ambivalence about 
the idea of being honest, upright, and dedicated to official goals. "Someone who readily believes whatever official discourse says has no independent thought." ${ }^{\text {37 }}$ 'Independence,' 'individualism,' 'civic rights' in totalitarian societies are channeled through distance, 'doublethink' and 'double-deed.' In his classic novel [1984], Orwell defines doublethink as "the power of holding two contradictory beliefs in one's mind simultaneously."

"The Party intellectual knows in which direction his memories must be altered; he therefore knows that he is playing tricks with reality; but by the exercise of doublethink he also satisfies himself that reality is not violated.... [T]he essential act of the Party is to use conscious deception while retaining the firmness of purpose that goes with complete honesty. . . . To tell deliberate lies while genuinely believing in them . . all this is indispensably necessary". ${ }^{38}$

Taken out of humorous contexts and into the everyday workings of society, the knowing smile - whether as a sign of recognition, misrecognition, or both - serves to point out open secrets, tensions or ambiguities, that individuals are forced to resolve themselves whether they deny, accept, fight or benefit from the existing gap between the official discourse and the way things get done in practice. Bridging that gap is left to individuals, which is well-illustrated in an early Soviet anekdot. A politburo member is giving a speech about industrialization and twenty-storey skyscrapers recently built on Karl Marx Street in Kharkov. Suddenly one of the listeners interrupts him:

'Comrade Kalinin, I am from Khar'kov. I walk down that street every day, but I have not seen any skyscrapers!'

'Comrade,' replies Kalinin, 'instead of loitering on the streets you should read newspapers and find out what's going on in your city. ${ }^{39}$ 
In tune with this folklore, Arendt theorizes totalitarian ideologies as those aiming not at the transformation of the outside world but at the transformation of human nature. ${ }^{40}$ Within two decades of her analysis, Zinoviev published his The Yawning Hights and Homo Sovieticus, and Levada provided the post-Soviet empirical evidence for the Homo Sovieticus diagnosis:

The Soviet experiment produced not so much a new human type as an individual who was wholly adapted to Soviet reality, one willing to accept it as a given, with no alternative. A society that was closed on all sides, even from its own historical reality, raised generations who could not imagine any way of life except the one they were given. The lack of alternatives turned the universal practice of adaptation into a habit, a mass behavioral structure that was neither dissected nor subject to analysis. ${ }^{41}$

In his 2001 analysis, Levada phrases it sharply and suggests little change in the Homo Post-Sovieticus's attitude to ethics.

At the individual level, the whole system of deals made with the state, which was intrinsic to the Soviet arrangement, inevitably led to moral corruption, the acceptance of sham, the padding of figures, string pulling, bribery, and doublethink. These conditions were necessary if society and the economy were to function. The collapse of the Soviet system did not introduce anything fundamentally new; it only eliminated the social and institutional (punitive) regulators that had limited the effect of the corrupting mechanisms. ${ }^{42}$

In his deconstruction of the dichotomy between 'officials' and 'people,' Alexei Yurchak analyses the role that political ridicule by the powerless played in expressing their 
relationship with the authority. He argues that the stagnation resulted in people's perception of official ideological representation of social reality as largely false but at the same time as immutable and omnipresent. "In such conditions it became irrelevant whether people believed official ideological messages or not." Instead, the relation to the officialdom became based on intricate strategies of simulated support and on 'nonofficial' practices. Yurchak argues that such a changing relationship between citizens and power eventually resulted in the ideological change that occurred in the mid-1980s. ${ }^{43}$

Given the importance of socialization in producing knowing smiles, one might imagine that changes in bringing up and educating younger generations could lead to the evaporation of Soviet-style practices. Yet the legitimacy of informal practices among the younger generations in Russia remains in place. ${ }^{44}$ Levada's data suggests that groups under forty find evasion of military service justified: the youngest respondents, directly subject to conscription, are more than twice as likely to justify draft evasion as to condemn it. ${ }^{45}$ Consequent knowing smiles, competence in draft evasion know-how and the doublethink about civic duty are thus set in motion. Unless such open secrets are articulated, explained or integrated into policies and cultural exchange, the fundamental non-transparency of societies is not going to diminish. ${ }^{46}$

The near ubiquitous exchange of knowing smiles in everyday contexts and their capacity for maintaining ambiguity up to now mostly has escaped dissection and analysis. Yet such exchanges are the basis of normality and routine interaction that is so fundamental for the modus operandi in societies according to Goffman. ${ }^{47}$ The function of knowing smiles is that by dismissing their importance and by accepting commonplaces that rules out reflection upon them, they reproduce unwritten rules and open secrets and 
thus the system of power based on everybody's complicity in it. In other words, smiling at open secrets is an acceptance that is conducive to the non-contestation of power. Knowing smiles are the integral part of maintaining the ambiguity about the official discourse of power elites and the unwritten rules they rely on to continue to stay in power. One is forced to keep open secrets a secret while also following the unwritten rules and fluently engaging in informal practices that bridge the gaps between formal constraints of the system and its informal impositions. Such an arrangementt makes one the insider of the system but also makes one complicit and fundamentally dependent on the system. The system makes people complicit in their own demoralization and their own corruption. ${ }^{48}$

My experience in Russia is not unique. In his recent book on talk and silence about corruption in the Pacific Islands, Peter Larmour observes that when he mentions he is doing research on corruption, peoples' faces tend to 'light up. ${ }^{49}$ In contrast to the dangers of studying corruption, intricacies of fieldwork abroad, and epistemological taboos of research into 'shadows', as Carolyn Nordstrom calls it, my focus here is on mundane behavior. Smiling at open secrets is no doubt in some ways a universal practice, not restricted to the Soviet doublethink or to its post-Soviet reincarnation. People do not have to live under the Soviet system to smile at the anekdot of its six paradoxes. The context of telling an anekdot prepares one for smiling and provokes a smile of recognition of a different kind, not necessarily of familiarity with the reality of socialism but of ambiguity, or the unfolding of paradoxes, or by proxy of one's own experiences. The manipulative use of the formal rules and using them to one's own personal advantage may be particularly strong in repressive systems but is not limited to them. This is illustrated by the studies of corruption and rent-seeking behavior in the Middle East, 
Asian, Latin American and African resource-rich economies, as well as in the recent analyses of the 2008 sub-prime crisis elsewhere ${ }^{50}$ On a wider scale, Sloterdijk identifies a universal trend of diffuse cynicism in modernity and an ironic treatment of ethics and of social conventions, "as if universal laws existed only for the stupid, while the fatally clever smile plays on the lips of those in the know". 51

Reflection on my years of fieldwork in post-Soviet Russia has helped to generate further questions. Knowing smiles are partially about smiling, partially about knowing. Knowing open secrets is partially about knowing, partially also about not knowing and not questioning. It is sign of awareness of transgression but also of recognition of things one does not need to spell out. Masked hostility - expressed through ribbing - towards the researcher 'daring' to expose all this to the light is indicative of these tensions. The semi-taboos against knowing, the complicity to leave things unarticulated, the ambiguities hidden behind open secrets are all pointers to sensitive subjects that could lead to innovative research.

\section{References}

Alexopoulos, Golfo. "Soviet Citizenship, More or Less: Rights, Emotions, and States of Civic Belonging”, Kritika: Explorations in Russian and Eurasian History, 7, no. 3, 487-528 (2006).

Arendt, Hannah. The Origins of Totalitarianism. San Diego, London: Harcourt, 1968.

Bourdieu, Pierre. Distinction: A Social Critique of the Judgment of Taste. London: Routledge, 1989. 
Boym, Svetlana. Common Places: Mythologies of Everyday Life in Russia. Cambridge: Harvard University Press, 1995.

Daniels, Robert V, The Rise and Fall of Communism in Russia, New Haven: Yale University Press, 2007.

Ekman, Paul, Emotions Revealed: Understanding Faces and Feelings. London: Widenfeld and Nicolson, 2003.

Ekman, Paul, Telling Lies: Clues to Deceit in the Marketplace, Politics and Marriage. New York: W.W. Norton \& Company, 1993.

Fitzpatrick, Sheila. "Blat in Stalin's Time.” In Bribery and Blat in Russia: Negotiating Reciprocity from the Middle Ages to the 1990s. Edited by. Stephen Lovell, Alena Ledeneva and Andrei Rogachevskii. Basingstoke: Macmillan, 2000.

Fitzpatrick, Sheila. Everyday Stalinism: Ordinary Life in Extraordinary Times: Soviet Russia in the 1930s. New York: Oxford University Press, 2000.

Fitzpatrick, Sheila. "Happiness and Toska: An Essay in the History of Emotions in Prewar Soviet Russia." Australian Journal of Politics and History, 50, no. 3, 357-371 (2004).

Frye, Timothy M. Brokers and Bureaucrats: Building Market Institutions in Russia, Ann Arbor: University of Michigan Press, 2000.

Goffman, Erving. The Presentation of Self in Everyday Life. Harmondsworth: Penguin, 1971.

Graham, Seth. "Varieties of reflexivity in the Russo-Soviet anekdot." In Reflective Laughter: Aspects of Humour in Russian Culture, Edited by Lesley Milne. London: Anthem Press, 2004. 
Gudkov, Lev, Negativnaya Identichnost': Stat'i 1997-2002 godov. Moscow: Novoe Literaturnoe Obozrenie, 2004.

Humphrey, Caroline. "Inequality and exclusion: A Russian case study of emotion in politics.” Anthropological Theory, 1, No. 3, 331-353 (2001).

Ledeneva, Alena. "From Russia with Blat: Can Informal Practices Help Modernize Russia?" Social Research 76, no.1 (2009).

Ledeneva, Alena. “Telephone justice in Russia.” Post-Soviet Affairs 24, no.4 (2008).

Ledeneva, Alena. How Russia Really Works: Informal Practices in the 1990s. Ithaca:

Cornell University Press, 2006.

Ledeneva, Alena. Unwritten Rules: How Russia Really Works. London: Centre for European Reform, 2001.

Ledeneva, Alena. Russia's Economy of Favours: Blat, Networking and Informal Exchange. Cambridge: Cambridge University Press, 1998.

Ledeneva, Alena. "Informal Institutions and Informal Networks: the Study of Blat." PhD thesis, University of Cambridge, 1996.

Levada, Iurii. “Homo Post-Sovieticus.” Sociological Research 40. no.6 (2001).

McNeill, Daniel. The Face: A Natural History. Boston, MA: Little, Brown, 1998.

Millar, James. "The Little Deal: Brezhnev's Contribution to Acquisitive Socialism." Slavic Review 44, no. 4 (1985).

Milne, Lesley, ed. Reflective Laughter: Aspects of Humour in Russian Culture. London: Anthem Press, 2004. 
Nordstrom, Carolyn. Shadows of War: Violence, Power, and International Profiteering in the Twenty-first Century. Berkeley, London: University of California Press, 2004.

Roth-Ey, Kristin. Soviet Culture in the Media Age. Forthcoming

Scheppele, Kim Lane. Legal Secrets: Equality and Efficiency in the Common Law. Chicago: University of Chicago Press, 1988.

Simmel, Georg. "The Sociology of Secrets and of Secret Societies." American Journal Society 11, no.4 (1906).

Sloterdijk, Peter. Critique of Cynical Reason. Minneapolis, London: University of Minnesota Press, 1987.

Tilly, Charles. Why? Princeton, N.J.: Princeton University Press, 2006.

Veblen, Thorstein. The Theory of the Leisure Class: The Challenging Analysis of Social Conduct That Ironically Probes Misused Wealth and Conspicuous Consumption. New York: Vanguard Press, 1962.

Yang, Mayfair M. Gifts, Favours and Banquets: The Art of Social Relationships in China. Ithaca \& London: Cornell University Press, 1994.

Yekelchyk, Serhy. "The Civic Duty to Hate: Stalinist Citizenship as Political Practice and Civic Emotion (Kiev, 1943-53)" Kritika: Explorations in Russian and Eurasian History, 7, no. 3, 529-556 (2006).

Yurchak, Alexei. "The Cynical Reason of Late Socialism: Power, Pretence, and the Anekdot." Public Culture 9 (1997).

Zhvanetskii, Mikhail. "Nepevodimaia igra" in Izbrannoe. Moskva: Eksmo, 2009, pp.131133 (originally recorded at the 1986 New Year eve performance). 
${ }^{1}$ Alena Ledeneva, Russia's Economy of Favours: Blat, Networking and Informal Exchange (Cambridge: Cambridge University Press, 1998).

2 Oxbridge unwritten rules are spelt out in F.M. Cornford, Microcosmographia Academica.

${ }^{3}$ Ledeneva, Unwritten Rules: How Russia Really Works (London: Centre for European Reform, 2001), 4-5.

${ }^{4}$ Douglass North, Institutions, Instituional Change and Economic Performance. (Cambridge: Cambridge University Press, 1990).

${ }^{5}$ The Russian Review, Vol. 45, (1986): 115-181.

${ }^{6}$ Some Moscow observers note that under President Putin the law enforcement is just as selective and law enforcement agencies appear to be pursuing corruption allegations almost exclusively when they involve known opponents of the Kremlin ${ }^{6}$. A variety of 'official' legal, administrative and economic sanctions can be levied against 'selected' victims. To start with, the fire brigade, tax police and sanitation department can be called upon to issue citations for tax irregularities or violations of fire, safety and public health codes on request. If necessary, this can be followed by further economic sanctions, informal arm-twisting, negative publicity in the press etc - a whole menu with legal changes for desert.

${ }^{7}$ Yuko Adachi, Building Big Business in Russia: The Impact of Informal Corporate Governance Practices, (New York: Routledge, 2010). 
${ }^{8}$ According to Interfax, Vladimir Makarov, the deputy head of the Interior ministry's economics crime department, said that up to 45 per cent of the country's goods and services are part of the shadow economy. He also said that more than 40 Moscow banks are involved in what he called 'serious' shady deals. These comments were echoed by Duma Security Committee chairman Alexander Kulikov, who told RIA-Novosti the same day that the treasury receives only 5 - percent of taxes owed because of operations in shadow economy [Quoted from RFE/RL, Vol. 5, No. 28, Part 1, 9 February 2001]. ${ }^{9}$ See Paul Seabright, The Vanishing Rouble. (Cambridge: Cambridge University Press, 2000).

${ }^{10}$ Personalities and relationships are just as essential the understanding of knowing smiles. See Charles Tilly, Why? (Princeton, N.J.: Princeton University Press, 2006), 1920.

${ }^{11}$ See Anthony Giddens, The Constitution of Society. (Berkley: University of California Press, 1986) on practical knowledge, and Michael Polanyi, The Tacit Dimension (Chicago: University of Chicago Press, 1983), on tacit knowledge.

${ }^{12}$ Georg Simmel, "The Sociology of Secrets and of Secret Societies," American Journal Society 11, no.4 (1906). Sharing a secret is often compulsive: when one cannot bear keeping a secret to oneself, one reloads the burden on another person to keep it.

${ }^{13}$ Erving Goffman, The Presentation of Self in Everyday Life (Harmondsworth: Penguin, 1971), 7-14. 
${ }^{14}$ See the discussion of sociology of secrecy in Kim Lane Scheppele, Legal Secrets: Equality and Efficiency in the Common Law (Chicago: University of Chicago Press, 1988), 3-23.

${ }^{15}$ Lesley Milne, ed., Reflective Laughter: Aspects of Humour in Russian Culture (London: Anthem Press, 2004), Introduction.

From the perspective of informal practices, I would not separate humour into official culture and unofficial culture that is co-opted in the building socialism and the alternative anekdot. Both helped to reproduce the façade of socialism.

${ }^{16}$ Note the censorship of Amalrik's Will the Soviet Union Survive until 1984?

${ }^{17}$ See Daniels 2007; Frye 2000; Ledeneva 2006.

${ }^{18}$ The Soviet system also failed to change individual needs, despite all its repressive potential and "experimental grounds of the concentration camps" Hannah Arendt, The Origins of Totalitarianism (San Diego, London: Harcourt, 1968).

${ }^{19}$ These boundaries are shifting as the implications of "smiling" in 1930s are different from, say, the 1950s and 1980s, as well as the implications of not smiling at the right times.

${ }^{20}$ Ledeneva, Russia's Economy of Favours, 79.

${ }^{21}$ Ledeneva. "From Russia with Blat: Can Informal Practices Help Modernize Russia?" Social Research 76, no.1 (2009); Alena Ledeneva, “Telephone justice in Russia," PostSoviet Affairs 24, no.4 (2008): 324-350.

${ }^{22}$ Gogol, Griboedov and Saltykov-Shchedrin quoted in Milne, Reflective Laughter. 
${ }^{23}$ According to modern communications research, understanding of emotions is instinctive and mostly wrong. As Paul Ekman says in his classic work, Telling Lies, nonverbal communication reliably signals the presence of emotion, but not the specific emotion.

${ }^{24}$ Ekman, Emotions Revealed, xiv.

${ }^{25}$ Mikhail Zhvanetskii, Nepevodimye igry (Recording of the New Year eve performance, 1986).

${ }^{26}$ Lev Gudkov, 2004.

${ }^{27}$ In contemporary Russia, for example, a simple reaction to success is to associate it with connections, corruption, or siloviki when it is really is_not just about that. "You can blame it all on blat when in fact it's not blat".

${ }^{28}$ Pierre Bourdieu, Distinction: A Social Critique of the Judgment of Taste (London:

Routledge, 1989).

${ }^{29}$ Erving Goffman, The Presentation of Self. (New York: Double, 1959).

${ }^{30}$ Ledeneva, Russia's Economy of Favours, 59-72.

${ }^{31}$ Ledeneva, Russia's Economy of Favours, 60.

${ }^{32}$ As one gender studies specialist pointed out, "it's a gender thing"--people smile because you are a woman and would be different in case a male researcher approached them on a similar subject.

${ }^{33}$ The AAASS panel on history of emotions in 2004 in Boston provided an inspiration, especially contributions by Sheila Fitzpatrick (see bibliography) and Ronald Grigor Suny 
on hatred. See also work by Caroline Humphrey, Golfo Alexopolous, and Serhy

Yekelchuk in the bibliography.

${ }^{34}$ Sheila Fitzpatrick, "Blat in Stalin's Time," in Bribery and Blat in Russia: Negotiating Reciprocity from the Middle Ages to the 1990s, eds. Stephen Lovell, Alena Ledeneva and Andrei Rogachevskii (Basingstoke: Macmillan, 2000); Sheila Fitzpatrick, Everyday Stalinism: Ordinary Life in Extraordinary Times: Soviet Russia in the 1930s (New York: Oxford University Press, 2000).

35 Simmel, "The Sociology of Secrecy", 442.

${ }^{36}$ See Kristin Roth-Ey, Soviet Culture in the Media Age (forthcoming), Chapter 1.

${ }^{37}$ Mayfair M. Yang, Gifts, Favours and Banquets: The Art of Social Relationships in China (Ithaca \&

London: Cornell University Press, 1994).

${ }^{38}$ Quoted in Iurii Levada, “Homo Post-Sovieticus," Sociological Research 40, no.6 (2001), 17.

${ }^{39}$ Quoted in Graham "Varieties of reflexivity”, 176.

${ }^{40}$ Arendt, The Origins of Totalitarianism, 458.

${ }^{41}$ Levada, "Homo Post-Sovieticus", 6-7.

${ }^{42}$ Levada, "Homo Post-Sovieticus", 9.

${ }^{43}$ Alexei Yurchak, "The Cynical Reason of Late Socialism: Power, Pretence, and the Anekdot," Public Culture 9 (1997), 162.

${ }^{44}$ For example, when a survey shows that among Russians today only 11 percent can say that they have "never lied to anyone," and only 32 percent can say that they "have never 
taken something that belonged to someone else without permission," it attests to one of the simplest and most widespread types of human deception. This type is based on the diversity of normative fields themselves (social, group, role, and other fields), which determine the orientations and frameworks of each individual's activity. What interests us, however, are the more specific types and structures of "deceptive" behavior that are linked to the specific functioning of social norms in particular historical and nation-state conditions - for example, the evasion of civic obligations and disobedience to the traffic rules (Levada, "Homo Post-Sovieticus").

${ }^{45}$ Levada, "Homo Post-Sovieticus"

46 The proposed analysis of open secrets and knowing smiles poses an empirical question of their universality/specificity. It is also worth pondering what forms of research might deepen our understanding of societies. Finally, one could pursue the line of analysis of the emotional content of corruption.

${ }^{47}$ Anthony Giddens, “On Rereading The Presentation of Self: Some Reflections,” Social Psychology Quarterly, 72 (4), (December 2009), 290-295.

${ }^{48}$ Now with a rear view image of the Soviet system, with all these things coming to the fore, we can start seeing without worrying if it is going to upset those who were complicit in their own repression.

${ }^{49}$ Peter Larmour, Understanding Corruption in the Pacific Islands, Honolulu: University of Hawaii Press, forthcoming. 
${ }^{50}$ See the materials of the British Council Conference, The Inner Life of Cultures.

Brussels, 25-26 February 2010 at http://www.counterpoint-online.org/the-inner-lives-ofcultures-papers

51 "Cynicism: The Twilight of False Consciousness", Ch.1 in Peter Sloterdijk, Critique of Cynical Reason, 3-4. 